\title{
The Interplay between Forest Management Practices, Genetic Monitoring, and Other Long-Term Monitoring Systems
}

\author{
Darius Kavaliauskas ${ }^{1, *}$, Barbara Fussi ${ }^{1}$, Marjana Westergren ${ }^{2}$, Filippos Aravanopoulos ${ }^{3}$, \\ Domen Finzgar $^{2}$, Roland Baier ${ }^{1}$, Paraskevi Alizoti ${ }^{3}$ (D), Gregor Bozic ${ }^{2}$ (1), Evangelia Avramidou ${ }^{3}$, \\ Monika Konnert ${ }^{1}$ and Hojka Kraigher ${ }^{2}$ \\ 1 Bavarian Office for Forest Seeding and Planting, Forstamtsplatz 1, 83317 Teisendorf, Germany; \\ barbara.fussi@asp.bayern.de (B.F.); roland.baier@npv-bgd.bayern.de (R.B.); monika.konnert@gmx.de (M.K.) \\ 2 Slovenian Forestry Institute, Vecna Pot 2, Ljubljana 1000, Slovenia; marjana.westergren@gozdis.si (M.W.); \\ domen.finzgar@gozdis.si (D.F.); gregor.bozic@gozdis.si (G.B.); hojka.kraigher@gozdis.si (H.K.) \\ 3 Aristotle University of Thessaloniki, University Campus, 54124 Thessaloniki, Greece; \\ aravanop@for.auth.gr (F.A.); alizotp@for.auth.gr (P.A.); aevaggelia@yahoo.com (E.A.) \\ * Correspondence: darius.kavaliauskas@asp.bayern.de; Tel.: +49-8666-988-350
}

Received: 31 January 2018; Accepted: 7 March 2018; Published: 10 March 2018

\begin{abstract}
The conservation and sustainable use of forests and forest genetic resources (FGR) is a challenging task for scientists and foresters. Forest management practices can affect diversity on various levels: genetic, species, and ecosystem. Understanding past natural disturbance dynamics and their level of dependence on human disturbances and management practices is essential for the conservation and management of FGR, especially in the light of climate change. In this review, forest management practices and their impact on genetic composition are reviewed, synthesized, and interpreted in the light of existing national and international forest monitoring schemes and concepts from various European projects. There is a clear need and mandate for forest genetic monitoring (FGM), while the requirements thereof lack complementarity with existing forest monitoring. Due to certain obstacles (e.g., the lack of unified FGM implementation procedures across the countries, high implementation costs, large number of indicators and verifiers for FGM proposed in the past), merging FGM with existing forest monitoring is complicated. Nevertheless, FGM is of paramount importance for forestry and the natural environment in the future, regardless of the presence or existence of other monitoring systems, as it provides information no other monitoring system can yield. FGM can provide information related to adaptive and neutral genetic diversity changes over time, on a species and/or on a population basis and can serve as an early warning system for the detection of potentially harmful changes of forest adaptability. In addition, FGM offers knowledge on the adaptive potential of forests under the changing environment, which is important for the long-term conservation of FGR.
\end{abstract}

Keywords: forest monitoring; forest genetic monitoring (FGM); forest genetic diversity; silviculture

\section{Introduction}

Forest management (FM) practices affect diversity on various levels: genetic, individual, population, species, and ecosystem [1-4]. As management has largely shaped the current state of forests, the contribution of future management to the maintenance of genetic diversity and increased resilience of forests [5] must be taken into account. Currently, there are many different types of FM practices, determined by factors such as climatic zones, forest types, site conditions, and even by the traditions of local societies [5]. Since 2000, a number of studies have been carried out to 
evaluate the impact of forest management on the genetic composition of various stands (e.g., [6-15]), with most of them focusing on a certain species or on a certain silvicultural system/management operation. Although the results derived from these studies are contradictory, most of them have found a management-associated impact on genetic structure and variation. Some studies advocate enhanced genetic diversity due to different FM practices [16]. However, these studies record only a snapshot of changes caused by FM practices and not their long-term effect on the genetic processes occurring in a stand. A detailed understanding of past disturbance dynamics and their relationship to human disturbances and management practices is essential for monitoring forest ecosystems exclusively in the light of predicted climate change [17-19]. By itself, this detailed understanding can be achieved only through FGM that will capitalize on the knowledge regarding existing FM practices in Europe and their impact on genetic diversity.

Several forest monitoring programmes have been implemented on national and international levels in Europe. On the international level, in 1985, the United Nations Economic Commission for Europe (UNECE-CLRTAP) launched the International Co-operative Programme on Assessment and Monitoring of Air Pollution Effects on Forests with the aim of monitoring the spatial and temporal variation of forest conditions in relation to anthropogenic and natural stress factors [20]. On the national level, forest monitoring is based mostly on National Forest Inventory (NFI) programmes, which provide data on the tree species, growing stock, increment, and status of timber and non-timber forest resources $[19,21]$. Although forest monitoring (e.g., International Co-operative Programme on Assessment and Monitoring of Air Pollution Effects on Forests) (ICP Forest)) and NFI provide relevant data indispensable for forest management and the conservation of ecosystems, they do not share common targets with a genetic monitoring approach.

The main idea behind FGM as defined by Namkoong et al. [22,23], who led the FAO Group on FGR, being among the first to propose the need for FGM, was to track evolutionary processes in forest tree populations using genetic and demographic indicators and verifiers needed to observe the changes caused by forest management in tropical forests at the scale of the forest management unit. This idea of tracking evolutionary processes based on indicators and verifiers, simplified in accord with the possibilities for implementation, was supported by EUFORGEN (established in 1994, www.euforgen.org), and remains so to this day [24-26]. In Germany, the Expert Group on the "Conservation of forest genetic resources" formulated a "Concept on a genetic monitoring for forest tree species in the Federal Republic of Germany" [27]. This FGM concept was first tested in a pilot study for two model species: European beech (Fagus sylvatica L.) and wild cherry (Prunus avium L.) [28], followed by other projects developing, testing, and implementing FGM: the FP7 project "FORGER" was partly focused on the development of FGM protocols [29], the Working Group on Genetic Monitoring within "EUFORGEN" developed a simplified concept of genetic monitoring [26], the Horizon 2020 project "GenTree" is currently testing genetic monitoring in four species (Fagus sylvatica L., Populus nigra L., Pinus silvestris L., Taxus baccata L.) [30], and the LIFE+ project "LIFEGENMON" [31] is the first implementation project testing indicators and verifiers for FGM to find the optimal combination given the questions asked and the means available at an international scale. On the national level, in Germany, the project "GenMon" has been establishing a network of FGM plots for Norway spruce (Picea abies (L.) Karst) (10 FGM plots) and European beech (Fagus sylvatica L.) (14 FGM plots) since 2016 [32]. Furthermore, a number of other national target developmental projects and tasks have been dedicated to pave the way for FGM at the national scale [32-37]. This high number of ongoing initiatives confirms the importance of the topic and the need for the implementation of FGM, especially under climate change when monitoring the adaptiveness of trees, stands, and ecosystems is of paramount importance [38-40].

The aims of this review are to: (i) compile existing forest management practices in Europe, (ii) evaluate the effects of these practices on genetic variation of forest stands and subsequently the need for genetic monitoring under different forest management types, (iii) gather and collate the existing forest monitoring information in Europe, and (iv) discuss the compatibility of the existing forest monitoring systems with the requirements of forest genetic monitoring. 


\section{Forest Management and Monitoring}

FM started in Neolithic times and intensified in the Middle Ages through forest exploitation and conversion to agricultural land [41]. Today, forests cover 33\% (215 million ha) of Europe, with $79 \%$ of this being available for wood production. Gross value added by the forest sector amounts to $€ 103$ billion or $0.8 \%$ of the European GDP yearly. More than 25 million ha (11.8\%) of forests are designated for the protection of water, soil, and biodiversity [42]. The current forest cover and wood production in Europe are largely connected to different types of FM practices determined by factors such as climate zone, forest type, and site conditions, as well as social factors like traditions and the aims of multipurpose forestry. While biogeographical and macro-climate conditions cannot be changed by forest management, silviculture can directly influence regeneration, species composition, stand density, age structure, and production, etc. [43], indirectly influencing genetic processes taking place in a stand [40].

One of the oldest FM practices is coppicing: trees are felled in a short rotation period (15-30 years) and sprouts are let to grow from the stumps. A coppice FM system can be even-aged (all trees within a specific area are logged at the same time) or uneven-aged (selected trees or small groups are harvested over a longer period). Forests are usually divided into blocks (compartments) which are harvested periodically, forming a continuous rotation. This kind of management protects the soil, while the uneven-aged coppice system favours shade-tolerant tree species [41]. Another FM type is coppice with standards; a two-story woodland management system where timber is produced from the overstory, and firewood from understory by following a short rotations system (15-30 years) [41]. High forests are forest stands that have originated from seeds or seedlings. These types of forests can be even-aged and uneven-aged. Even-aged forests are usually a result of clear-cutting, seed tree cuttings, or regular shelterwood. Uneven-aged forests are a result of irregular shelterwood or selective forest cutting [41]. The uneven-aged FM system is characterized by principles of perennation and the sustained yield of forest over small areas [6]. In the Mediterranean region, a transitional FM practice type is applied, namely the conversion of coppice to high forests [44]. To convert a coppice to high forest, gradual thinning of sprouts over a long span of time is usually required. Converting coppices into high forests with continuous cover has been used in recent decades as a management goal in hilly and mountainous Mediterranean areas for the mitigation of recurrent clear-cutting impacts on soil, landscape, and biodiversity conservation $[44,45]$.

Many authors have tried to classify silvicultural systems based on economic or ecological methodologies [46-48], e.g., Duncker et al. [43] categorized the silvicultural systems according to their management intensity into five different categories, called forest management approaches (FMAs). All five FMAs vary in intensity, objectives, and silvicultural operations applied (Table 1). According to Duncker et al. [43], a positive feature of FMA classification is flexibility, as the FMA may change over time for a forest ecosystem, so that specific objectives and goals can be met.

Table 1. Overview of Forest Management Approaches (FMAs) by Duncker et al. [43] and silvicultural operations linked to the need for FGM.




Table 1. Cont.

\begin{tabular}{|c|c|c|c|}
\hline $\begin{array}{l}\text { Forest Management } \\
\text { Approach (FMA) }\end{array}$ & $\begin{array}{l}\text { Forest Management } \\
\text { Intensity }\end{array}$ & $\begin{array}{l}\text { Natural Processes/Silvicultural } \\
\text { Operations within the FMA }\end{array}$ & $\begin{array}{l}\text { FGM Necessity } \\
\text { (Yes/No/Limited) }\end{array}$ \\
\hline $\begin{array}{l}\text { (IV) intensive even-aged } \\
\text { forestry }\end{array}$ & $\begin{array}{c}\text { Intensive management } \\
\text { with aim to produce } \\
\text { timber }\end{array}$ & $\begin{array}{l}\text { - natural regeneration and artificial regeneration (planting } \\
\text { and sowing) } \\
\text { - thinning } \\
\text { - clear-cuts with long rotation and all other types of } \\
\text { logging can be applied }\end{array}$ & No/Limited * \\
\hline $\begin{array}{l}\text { (V) short rotation } \\
\text { forestry }\end{array}$ & $\begin{array}{c}\text { Intensive management } \\
\text { with aim to produce } \\
\text { biomass }\end{array}$ & $\begin{array}{l}\text { - only planting or sowing } \\
\text { - clear-cuts }\end{array}$ & $\mathrm{No}^{*}$ \\
\hline
\end{tabular}

* When short rotation forestry is modified (due to different reasons) it might turn into even-aged forestry, and in this case FGM would be possible and needed.

Therefore, in Table 1, we highlight FMAs for which genetic monitoring, in our opinion, is considered necessary. As, for example, the genetic monitoring of unmanaged nature reserves (I) is necessary and can serve as baseline data for further FGM, additional monitoring of natural reserves will provide us with insight into the diversity of intact forest stands. In contrast, FGM is not needed in intensive even-aged (IV) and short rotation (V) forestry so long as the aim of those FMAs is wood or biomass production through intensive forest management (planting-cutting based FMAs). Despite the diverse aims of different FMAs, the genetic diversity of trees is important within each FMA as it can be directly linked with disease resistance or pest outbreaks [43]. Thus, the data and results obtained from genetic monitoring could be used in adaptive forest management to mitigate already existing and upcoming threats for managed forest resources [49].

\section{Impact of Forest Management Decisions on the Genetic Composition of Stands}

Forest management includes ecological, silvicultural, economic, landscape, wildlife, and recreational considerations. According to the management paradigm, managing tends to increase the number of forest ecosystem benefits and services in comparison with those obtained from unmanaged forests.

The so-called "close-to-nature" forest management approach [50] developed through decades of different sustainable forest management definitions and is a logical continuation of the 'natural silviculture' movement of the late 19th century that originated in central Europe. While the first forest management plans primarily perceived sustainability as an undisturbed system of constant wood production, the sustainability concept of close-to-nature management focused on multipurpose forestry with a high awareness of biodiversity, water resources, and climatic changes [51,52].

Forest management may influence the genetic composition of stands directly through the crop tree selection, different silvicultural systems, breeding, and seed transfer, and indirectly through changes in environmental conditions $[2,4,16]$. Hence, contemporary close-to-nature forest management should consider forest genetic diversity as a basis for successful forest biodiversity conservation. Below, a general overview is given on some of the critical factors that can affect genetic variation directly, e.g., different types of regeneration, seed source (quality, origin, etc.), wood harvesting types, and seed transfer.

Regeneration of a stand can be natural, natural combined with artificial by-planting (enrichment planting), or artificial regeneration by planting or sowing. The genetic structure of naturally regenerated stands depends on various factors: e.g., the number and spatial distribution of reproducing trees, pollen flow, seed dispersal, etc. [53]. According to Konnert and Hosius [8], in natural regeneration, generally no loss of genetic diversity should occur as long as the number of trees within the stand that effectively participate in the reproduction process is sufficiently large. However, natural regeneration can also differ from adult trees in genetic variability and structure when, for example, population sizes are drastically reduced through the severe felling of reproductive trees and only a low number of parents contribute to seed production for the next generation [54]. The same might happen when tree densities in rare or scattered species are low, which leads to less diverse parental combinations in the 
offspring generations. In terms of population genetics, such outcomes are collectively referred to as consequences of a low effective population size [55].

The consecutive removal of only a few old-growth trees from stands may have no essential impact on the genetic structure and variation of the natural regeneration, since the logging intensity is low and its spatial pattern across the stand varies each time it is applied. In this way, the progeny population consists of individuals of different age classes across the stand. The slow regeneration in small patches (shelterwood system) seems to allow for an unrestricted gene flow and thus for the dynamic conservation of genetic multiplicity $[3,8,14,56,57]$. In contrast, the seed tree regeneration method, which facilitates natural regeneration, can negatively influence the genetic diversity, heterozygosity, and multiplicity of the offspring generation if the number of remaining seed trees is small or isolated from neighboring pollen sources. Such conditions can build up genetic drift and loss of genetic variation and rare alleles $[41,56]$.

When artificial regeneration is applied, the genetic composition of the newly established stand will depend on the origin of seeds (e.g., seed stand, seed orchards, single trees, etc.). The number of trees from which the seed is collected is of vital importance to ensure genetic diversity in artificially regenerated stands or stands where enrichment planting is used $[8,58]$. It is generally accepted that genetic diversity is higher in the seed crop of seed orchards than in the seed collected from wild populations if the seed orchard consists of a high number of clones [2]. Apart from the origin of the forest reproductive material (FRM), seed harvesting procedures as well as the number of seedlings planted per unit area are very important factors for afforestation and reforestation. Seed treatment, stratification, and nursery procedures have only a minimal or less pronounced effect on the genetic structure of FRM [8]. When FRM is transferred from geographically, environmentally distant locations, intraspecific introgression followed by outbreeding depression may emerge, and offspring might possess genotypes and phenotypes that are not suited for the new environment $[59,60]$. To avoid the gene flow from maladapted planted genetic material which can have an impact on the genetic structure of neighbouring forests $[3,4,8]$ many counties have delineated provenance regions and implemented regulation for FRM transfer and trading at national and international levels (e.g., through EU marketing requirements for FRM [61,62]).

Natural regeneration can also be combined with artificial reforestation (enrichment planting). Enrichment planting can be used when the objective of management is to introduce or favour valuable species or to increase the number of species, or to supplement the stocking of the trees in areas where natural regeneration is insufficient or unevenly distributed [63]. Appropriately large species diversity and genetic diversity within species can guarantee adaptive potential and self-sustainability of tree populations at various site conditions $[64,65]$. Enrichment planting may ensure or enlarge the genetic diversity of natural regeneration if planted material (saplings) originates from seed orchards or seed stands with a high number of reproducing non-related clones/trees. By enrichment planting, the existing genetic variation of natural regeneration can be increased through the planting of FRM well adapted to the site (adaptiveness to the site ensures higher saplings survival and better growth) $[8,66,67]$.

Wood harvesting has a direct impact on the genetic diversity of populations through changes in population size, age distribution, density, spatial distribution of trees and genotypes, etc. Non-commercial forest species may also be affected by logging, as it causes alterations in environmental conditions for animals and plants [23]. Numerous studies, focusing on a one-time snapshot of the effect of logging (thinning, selective logging, etc.) on genetic diversity, have reported diverse findings; below, we describe a few different types of thinning for which genetic studies were available.

Thinning is a silvicultural operation aiming to reduce the density of trees in a stand in order to improve the quality and growth of the remaining trees and produce a saleable product. Objectives of thinning can also include altering of the species composition in a stand, improving the health of the remaining trees, or disturbing an established ground flora to promote natural regeneration $[56,68]$. In young stands, different thinning regimes (selective thinning, e.g., future-tree oriented thinning, 
thinning from above and thinning from below with varying intensities; systematic thinning, e.g., row thinning, strip thinning) resulted in small effects on genetic structure when thinning intensities were low to moderate $[3,9,15,69-72]$. Future-tree oriented thinning (aims to enhance the number of early-selected trees, whose growth is favored by applying thinning in their neighborhood [73]) appears to be beneficial for the conservation of FGR; if a high number of future trees are selected, the influence is only slightly different from natural selection [8]. Only a severe decrease in the number of trees in a stand (e.g., often during thinning from below with higher intensity) will lead to a loss of rare alleles, which results in a decrease of genetic multiplicity [8]. Selective thinning in older stands (e.g., thinning from above) may change the genetic structure of the next generation if the inferior phenotypes (e.g., trees with low stem quality, double top or suppressed trees because of slower growth) which were removed systematically were related to particular genotypes [56]. In particular, too early target diameter felling may have negative genetic consequences if fast-growing trees are removed before their reproductive maturation [3].

The number of reproductively mature trees in the unit of area also has an impact on the spatial genetic structure of the next generation when population density is lower than 25 reproductively mature trees ha ${ }^{-1}$ if seeds disperse over a short distance [74] or when the density of adult reproductive trees is only a few individuals per population, which occurs when species recolonize deforested areas [75]. Spatial genetic structure is a key factor determining the short-term evolutionary potential of a population [76]. The number of crop trees (trees selected to be kept in the stand after thinning) in the stand is species dependent and varies according to national tending models (e.g., German, Swiss, German-French, etc.). Contemporary models focus on lower numbers of crop trees than older ones. Having said that, tending recommendations for the number of crop trees in species like Fagus sylvatica L. vary by more than $100 \%$ and propose thinning in different developmental stages of trees [77]. Such differences in models influence the genetic structure of forest stands, since the stand density and spatial structure of adult trees affect the spatial genetic structure of natural regeneration [78].

Logging (commercial logging) for the production and trade of timber or biomass is performed on mature stands and is generally categorized into two groups: selective (planter forest) and clear-cutting. Selective forest logging-which can also be described as selective forest thinning in older forest stands-is applied when different age classes and mixtures of tree species occur in single stands, and as a result, continuous wood production over a long time is expected, and only improvement-tending, selective cuts, or thinning to support natural regeneration are applied annually or over short periods (e.g., five to seven years [57]). This type of FM relies on the occurrence of shade tolerant species such as silver fir and common beech $[41,52,57]$. Because of the continuous renewal of the trees, as the forest is never completely cut down and always contains a variety of trees of different sizes, ages, and species, over time, it is generally assumed that this type of management is advantageous for maintaining genetic diversity and adaptability [6]. Konnert and Hussendörfer [6] compared genetic multiplicity and diversity of silver fir (Abies alba Mill.) in two contrasting management systems-the uneven-aged ("Plenterwald") and the even-aged forest in Germany. They concluded that from a genetic standpoint, uneven-aged forests are advantageous for genetic diversity when dealing with very small stands and/or with stands with a low percentage of silver fir, while even-aged stands can be advantageous if the stand area is large, the number of reproducing silver fir trees is high, and the regeneration occurs over a long time in small patches [6]. Wernsdörfer et al. [9] modelled the impact of selective cutting on genetic factors (e.g., genetic diversity, selfing, number and location of fathers, mating success, population size versus genetic diversity, etc.) and demography (juvenile mortality) in tropical forests. Simulations revealed that the mortality of natural regeneration had the highest impact on the number of alleles and genotypes, and on the genetic distance between the parental and offspring populations. Selfing had the highest effect on the fixation index and observed heterozygosity, but in general, selective cuttings had a greater impact on population size than on genetic variation. They concluded 
that forest management should primarily consider the regeneration capabilities of the tree species to be harvested [9].

The shelterwood system includes several types of cuttings, e.g., regular shelterwood, strip shelterwood, wedge shelterwood, and irregular (group) shelterwood [41]. Regular shelterwood cuttings are based on the regular and gradual opening of the canopy to initiate natural regeneration. This type of management can maintain genetic diversity over time and space, as a slight opening of the stand usually enhances natural regeneration [54,79]. A disadvantage of the regular shelterwood management is that natural regeneration originates mainly from a single seed year, posing a risk that not all (or not the majority of) adult trees will have a parental contribution to the next generation. The irregular (group) shelterwood system is used mainly for mixed forests and results from group selection felling, while natural regeneration is initiated by irregular openings of the canopy. The initial openings are gradually enlarged by peripheral fellings, resulting in cohorts of regeneration [41]. In the scientific literature, descriptions of irregular shelterwood systems may vary, but the common objective is to establish, at each entry, a new cohort composed of desirable species, with a longer regeneration period than a regular system $(>20 \%$ of rotation length) [80]. This system can consider the seeding dynamics of the tree species, while the long regeneration cycles ensure the similarity of genetic composition among the parental and the offspring populations [81]. In contrast, the strip shelterwood management system can be used in mixtures containing light-demanders (pine or larch), moderate shade-bearers (spruces or sycamore), and shade-bearers (beech or silver firs), and its main advantages are the sheltered regeneration of the sites and the control of micro-climate through the use of overhead and side shade [82]. Natural regeneration in this system can be composed of saplings produced in several seed years and with the contribution of seeds/pollen from various trees and ideally the whole number of progenitors [41].

Clear-cutting with standards or the seed-tree method removes most of the mature trees and only a few reproductively mature trees are maintained as a seed source. The number of remaining trees following this type of cutting is extremely low: 5-10 trees ha ${ }^{-1}$ [83]. Remaining trees have a scattered distribution and do not provide appropriate shelter to the emerging natural regeneration [41]. This management system provides the opportunity to influence the seed source and the genetic diversity of the next generation through the seed tree selection, but it is considered an inferior one from a genetic point of view due to the relatively small number of adult trees and the expected lower genetic diversity of the next generation [41].

Clear-cutting with artificial regeneration was generally used as a financially profitable type of FM. In this system, all trees are cut at once in a certain area, and at long time intervals. In the 18th and 19th centuries, most European forests were managed using clear-cuttings followed by artificial regeneration (seeding or planting). As a result, many broadleaf forests were converted to light-demanding, faster growing, coniferous ones in Central Europe [5,41]. Under this system, the genetic diversity of the next generation strongly depends on the genetic composition of the reproductive material used for afforestation (e.g., origin of seed used for artificial regeneration-collected from seed orchards, plus trees, or even from a single tree, etc.). From an ecological point of view, effects caused by clear-cuttings on water, microclimate, soil, nutrient cycling, and diversity and composition of plant and animal species are in most cases negative or even harmful $[52,84]$.

Overall, the impact of FM on the genetic variation of forests depends on numerous factors such as the management system applied, stand structure, species biology, distribution, and demography [4]. Schalberg et al. [16] emphasized that not all FM scenarios have a neutral or negative impact on genetic variation. Depending on the management type, intensity, and selection criteria applied, genetic diversity can be maintained or even enhanced $[4,16]$. Table 2 summarizes the main forest management practices and presents their key features, together with the most recent studies (2000 onwards) relevant to the genetic effects resulting from the application of each forest management practice. 
Table 2. Compilation of forest management practices and related studies focusing on the influence of FM practices on genetic variation of forest stands.

\begin{tabular}{|c|c|c|c|c|}
\hline Forest Management Practices & $\begin{array}{l}\text { Key Features and Type of } \\
\text { Cuttings/Silvicultural } \\
\text { Operations Applied }\end{array}$ & Tree Species on which Each Forest Management Practices can be Applied & $\begin{array}{l}\text { FM Practices Applied among } \\
\text { “LIFEGENMON" Countries }\end{array}$ & $\begin{array}{l}\text { References } \\
\text { (since 2000) }\end{array}$ \\
\hline Coppicing & $\begin{array}{l}\text { - trees felled in a short rotation } \\
\text { (15-30 years); } \\
\text { - shoots let to grow from the } \\
\text { base (stump); } \\
\text { - clear-cutting; } \\
\text { - selective forest cutting; }\end{array}$ & $\begin{array}{l}\text { Species with sprouting capacity and mainly: oaks (Quercus spp.-Quercus pubescens } \\
\text { Willd.; Quercus cerris L.), ash (Fraxinus spp.-Fraxinus ornus L.);), chestnut (Castanea } \\
\text { sativa Mill.), common alder (Alnus glutinosa L.), hornbeam (Carpinus betulus L.); } \\
\text { sweet chestnut (Castanea sativa Miller); beech (Fagus sylvatica L.); black locust } \\
\text { (Robinia pseudoacacia L); European hop-hornbeam (Ostrya carpinifolia Scop.) }\end{array}$ & $\begin{array}{l}{ }^{*} \text { Germany }<1 \% \\
{ }^{* *} \text { Slovenia } 5 \% \\
{ }^{* * *} \text { Greece } 48 \%\end{array}$ & [85-92] \\
\hline Coppice with standards & $\begin{array}{l}\text { - two-story woodland; } \\
\text { - overstory to produce the } \\
\text { timber; } \\
\text { - understory to produce } \\
\text { firewood within short rotations } \\
\text { (15-30 years); }\end{array}$ & $\begin{array}{l}\text { Species with sprouting capacity and mainly: oaks (Quercus spp.), sycamore } \\
\text { (Acer spp.), birch (Betula spp.), elm (Ulmus spp.), common hazel (Corylus avellana L.), } \\
\text { cherry (Prunus spp.) }\end{array}$ & $\begin{array}{c}* \text { Germany }<1 \% \\
{ }^{* *} \text { Slovenia }<0.5 \% \\
{ }^{* * *} \text { Greece } 17 \% \text { (mixed stands } \\
\text { with coniferous high forests and } \\
\text { broadleaved coppice forests) }\end{array}$ & [87] \\
\hline $\begin{array}{l}\text { Transition from coppicing to a } \\
\text { high forest }\end{array}$ & $\begin{array}{l}\text { - gradual thinning of sprouts; } \\
\text { - selective forest cutting; }\end{array}$ & $\begin{array}{l}\text { Applied on tree species with sprouting capacity: from coppice with inclusion of } \\
\text { other native tree species for transition to high forests. }\end{array}$ & ${ }^{* *}$ Slovenia $<2 \%$ & [89] \\
\hline High forests & $\begin{array}{l}\text { - stands originated from seeds } \\
\text { or seedlings; } \\
\text { - thinning; } \\
\text { - selective forest cutting; } \\
\text { - regular/irregular shelterwood; } \\
\text { - clear-cutting with artificial } \\
\text { regeneration; } \\
\text { - seed-tree-silviculture method; } \\
\text { - etc. }\end{array}$ & Applied on all tree species (sprouting and non-sprouting ones). & $\begin{array}{l}* \text { Germany } 98 \% \\
* \text { Slovenia } 93 \% \\
* * * \text { Greece } 35 \%\end{array}$ & {$[6,7,10-15,67,70-72,87,91-125]$} \\
\hline
\end{tabular}


Reviewed studies (Tables 2 and 3) revealed inconsistent results; different species responded differently to forest management operations, both demographically and genetically. A high number of studies (29 out of 50) found no evidence of management impact on genetic diversity, while 16 studies out of the remaining 21 found significant evidence of genetic variation decrease due to management. Eight studies observed changes in the mating system (gene flow, inbreeding), and eight studies found significant changes in the spatial genetic structure.

Table 3. Summary of studies on genetic effects of forest management practices.

\begin{tabular}{|c|c|c|}
\hline $\begin{array}{c}\text { Genetic Effects Caused by Forest } \\
\text { Management }\end{array}$ & $\begin{array}{c}\text { Type of Markers Used } \\
\text { (Dominant/Co-Dominant) }\end{array}$ & References (since 2000) \\
\hline \multirow{2}{*}{$\begin{array}{l}\text { No significant changes in genetic } \\
\text { structure and diversity }\end{array}$} & Dominant & {$[11,97,98]$} \\
\hline & Co-dominant & $\begin{array}{c}{[7,9,11-14,67,70,71,85,88,89,91,92,101,102,104,107,} \\
109,114-116,121,123-125]\end{array}$ \\
\hline \multirow{2}{*}{$\begin{array}{c}\text { Changes in spatial genetic } \\
\text { structure }\end{array}$} & Dominant & - \\
\hline & Co-dominant & {$[12,71,92,94,111,112,117,124]$} \\
\hline \multirow{2}{*}{ Changes in mating system } & Dominant & [113] \\
\hline & Co-dominant & {$[10,90,96,99,103,120,122]$} \\
\hline \multirow{2}{*}{$\begin{array}{l}\text { Changes in averaging genetic } \\
\text { diversity parameters }\end{array}$} & Dominant & [97] \\
\hline & Co-dominant & {$[6,15,72,90,93,95,100,102,106,108,114,117-119,122]$} \\
\hline
\end{tabular}

Part of the studies showed inconsistent results, e.g., Carneiro et al. [122] reported reduced genetic diversity because of selective logging, but an increased number of effective pollen donors, and was included two times in the Table 3. However, all the studies represent only a snapshot of and one-time insight into existing situations, and not long-term research. Subsequent management interventions, in the same stand, may lead to the gradual loss of genetic diversity in the offspring generations, which for tree species, may take decades $[105,130]$. Therefore, to detect the impact of natural and human disturbances (management impact) on the genetic variation of forest tree populations over time, data from several repeats of appropriately sampled research plots (e.g., managed vs. unmanaged) are needed [12]. Thus, in order to fully understand how management systems affect the sustainable use of forests and their conservation in the long term, FGM can serve as an appropriate tool. However, for an effective monitoring programme with respect to the detection of management impact, it is first necessary to assess the baseline data, i.e., the random fluctuations of a population's genetic structure, in order to be able to detect genetic changes caused by anthropogenic factors later on [131].

\section{Monitoring Systems}

\subsection{Long-Term Monitoring of the State/Condition of Forests}

To detect interactive effects of anthropogenic and natural stress factors on the condition of forest ecosystems, various monitoring schemes were launched at the national (e.g., National Forest Inventories (NFI)) and international levels (e.g., ICP Level I and II sites) (e.g., [132]). Some existing monitoring schemes were established to monitor changes in site conditions and species diversity, caused by different environmental factors, but not by forest management (e.g., ICP Level I and II sites), while NFI can provide long-term information on the status of forest stands affected by forest management. Environmental monitoring can be described as a group of systematic studies that reveal the state of the environment in different time intervals. For example, the ICP Forest monitoring system regularly assesses the status of the environment (e.g., ecosystems, biodiversity, forests etc.) and helps to detect any changes occurring within those environments [20]. Below, we compile and describe the monitoring schemes NFI, ICP Forests, and Long-Term Growth and Yield plots, in view of their usefulness for the simultaneous implementation of FGM. 


\subsubsection{National Forest Inventories (NFI)}

Forest inventory is a systematic survey to determine, in a given area, data for forest management or taxation, or serve as a basis for forest policies and programmes in a given country [133]. The data recorded by NFI include, inter alia, location, access, topography, soil condition, water course, flora and fauna elements, and composition and constitution of the forests. NFIs methodologies differ among countries, but the majority of them are designed as tracts located on a systematic grid with several concentric sampling plots [19]. The inventories provide information on forest health, increment, volume of growing stock per tree species, and condition of non-timber forest resources. Presently, NFIs are progressing towards multipurpose resource assessments and are expanding their scope to accommodate additional variables such as biodiversity assessment that are not directly related to timber harvesting [19].

\subsubsection{ICP Forests}

One of the aims of the ICP Level I monitoring system is to gain a better understanding of the cause-effect relationships between the condition of forest ecosystems and anthropogenic as well as natural stress factors (especially air pollution) by means of intensive monitoring on a number of selected permanent observation plots spread over Europe and to study the development of important forest ecosystems [20]. Therefore, the forest condition is observed annually based on a $16 \times 16 \mathrm{~km}$ grid net covering around 7500 plots in Europe. For some plots, soil and foliar analyses are being additionally carried out [20]. The ICP Level II intensive monitoring sites [20] are dedicated to investigating in-depth the interactive effects of anthropogenic and natural stress factors on the condition and development of the forest ecosystems. As such, it requires data to cover a range of responses (from tree condition to growth and biodiversity), predictors (e.g., deposition, gaseous air pollutants, meteorology), and intermediate variables (having the role of both response and predictors, according to the analysis, e.g., soil, soil solution and foliar nutrition) [17]. In short, Level II envisages a large number of measurements on a limited number of plots installed in the main forest ecosystem types. However, ICP Forests sites are situated in 42 countries covering only a very small percentage of the European forests (e.g., ICP Level II covers only approximately 155 ha (618 active plots) and ICP Level I approx. 1500 ha (over 7500 active plots) [134]) and unfortunately not all types of ecosystems and environmental/climatic conditions are included in this monitoring system. Because of the low representation of specific areas/regions and the deficient ecological and genetic background data, Mátyás [135] emphasized that data from ICP Forests are only of limited use.

4.1.3. Long-Term Growth and Yield Observation and Experimental Plots (Forest Growth Plots under Different Management Systems in Pure and Mixed Forest Stands)

In the late 19th century the first long-term forest observation and experimental plots were established in Central Europe. In 1892, the Association of German Forest Research Stations reviewed the composition and aims of the Association and together with forestry research institutes of Germany, Austria, and Switzerland, established the International Union of Forest Research Organizations (IUFRO) to supervise this network. IUFRO's aim was to ensure the continuity and standardization of long-term forest growth and yield experiments. Most of these monitoring plots were focused on the growth and yield of individual trees, stands, and provenances under different management types and intensities, in pure and mixed forest stands. Unthinned reference plots were established simultaneously. Many of those observation plots are still an important part of the forest observation network in Central Europe. Those plots provide data about diameter at breast height (DBH), height, basal area, and volume of trees. Long-term experimental plots have the advantage of providing historical information about the stand (all disturbances, management regimes etc. are recorded), their experimental setup is standardized, and they often include completely unmanaged plots. Since the beginning in 1870, most long-term observation plots have been re-measured more than 20 times up until now $[136,137]$. Data gained from monitoring systems like the one for long-term growth and yield 
plots give results and direct hints for forest management under climate change and can improve FGM with supplementary data.

Conservation of forest ecosystems, sustainable use of forest resources, and sustainable forest management are the main goals of monitoring programmes in forest ecosystems at the national and international levels $[138,139]$. However, the monitoring of genetic diversity, one of the main elements in the maintenance of biodiversity at all other levels (i.e., species, ecosystem, etc.), has been ignored in all forest monitoring programmes up to now, mainly because genetic diversity was expensive and difficult to measure directly [138-140]. Still, genetic monitoring has been recognized as a necessary part of biodiversity monitoring with the Convention on Biological Diversity [141] and has been discussed and under development as a concept for the last 20 years.

\subsection{Monitoring the State of the Genetic System of Forests (FGM) and Its Development}

Different theoretical concepts of FGM have been under development for the last two decades [22-24,26,27,140,142-146], while the first national initiative of its implementation started in Germany in 2004 [28]. The pilot implementation was based on the "Concept of a Genetic Monitoring for Forest Tree Species in the Federal Republic of Germany" [27] formulated by a working group of forest geneticists. Diverse results and practical experience gained from this study showed the necessity and urgency for developing and implementing a genetic monitoring system [28].

Following the first implementation of FGM in Germany, several European projects took up research on FGM and its implementation. The project "FORGER" (Towards the Sustainable Management of Forest Genetic Resources in Europe-completed in 2015) aimed inter alia to develop a common protocol for measuring and monitoring genetic diversity [29] and used it in a pilot study of four European forest tree species. In each plot, adults, seedlings, and seeds were sampled and genetically analysed using two types of molecular markers (SSR and SNP). Spatial geographic structure and demographic parameters were analysed together with genetic data. However, the project did not install long-term monitoring plots and rather relied on a standard population genetic study approach taking advantage of the presence of multiple age cohorts in a single stand.

Nowadays, two ongoing European projects deal with FGM; the LIFE project LIFEGENMON (LIFE for European Forest GENetic MONitoring System [31]) and the Horizon 2020 research project "GenTree" (Optimising the management and sustainable use of forest genetic resources in Europe [30]). The LIFEGENMON project (www.lifegenmon.si) is the first implementation project aiming to establish and put into practice a long-term FGM system at an international scale from the south of Germany to Greece. LIFEGENMON has established six long-term FGM plots, three for Abies species (two for A. alba Mill. and one for A. borisii-regis Mattf.) and three for Fagus sylvatica L., and is currently developing optimal indicators and verifiers for FGM from the information and cost effectiveness standpoint. The LIFEGENMON project seeks to develop guidelines for FGM of seven selected tree species, and to provide guidance on how to implement an optimal FGM solution to all relevant stakeholders across different countries and regions [139]. The aim of GenTree as a research project is to provide the European forestry sector with better knowledge, methods, and tools for optimizing the management and sustainable use of FGR in Europe in the context of climate change. GenTree will also aim to meet the increasing demands for forest products and services through the development of FGM focusing on the network of in-situ dynamic genetic conservation units (DCUs) and ex-situ collections [30].

According to the Strategic Plan for Biodiversity 2011-2020, the biodiversity targets up until 2010 were not achieved and the diversity of genes, species, and ecosystems continues to decline, mainly as a result of human actions. Additionally, the lack of integration of biodiversity issues into broader policies, international strategies, and programmes was highlighted [147]. The aim of the Strategic Plan for Biodiversity 2011-2020 is to promote effective implementation of the Convention (CBD) through strategic goals and targets (e.g., "the Aichi Biodiversity Targets"). One of the Aichi Targets (Aichi Biodiversity Target No. 13) emphasizes the importance of genetic diversity and seeks by 2020 to minimize genetic erosion and to protect the genetic diversity of wild and cultivated plants, farmed 
and domesticated animals, and the wild relatives of all cultivated and domesticated species [148]. In addition, the European Commission approved the EU Biodiversity Strategy 2020 to halt the loss of biodiversity and improve the state of Europe's species, habitats, ecosystems, and the services they provide. Therefore, actions $9 \mathrm{~B}, 10$, and 20 emphasize the protection and importance of genetic diversity and FGR [149]. In order to reach Aichi targets and implement EU Biodiversity Strategy actions, support mechanisms through policy and finances should be enhanced; accessibility, use, and sharing of knowledge must be supported, while access to other resources must be ensured. A good example is the EUFGIS database [150], implemented by the EUFORGEN network (www.euforgen.org [151]), an online information system for FGR in Europe. It was created to support the efforts of European countries to implement FGR conservation as part of sustainable forest management. The project focuses on improving the documentation and management of dynamic gene conservation units (GCU) of forest trees. GCUs have a designated status as conservation areas, a basic management plan that includes, among the major goals, the generation turnover and genetic conservation of forest trees, and a monitoring plan [25]. It is vital to further support and maintain the GCU network, as a basis for the further development and implementation of the FGM system at the pan-European level. In addition, similar programmes like the Conservation of Forest Genetic Resources in Canada (CONFORGEN) and the Asia Pacific Forest Genetic Resources Programme (APFORGEN) is following the work of EUFORGEN and seeks to protect and enhance the genetic diversity of FRM [152,153]. Dynamic conservation of genetic diversity emphasizes the maintenance of evolutionary processes in tree populations to safeguard their potential for continuous adaptation. In the face of climate change, this approach is essential for the long-term sustainability of forests and forestry in Europe [150].

The growing number of projects on FGM shows a clear mandate through the Convention on Biological Diversity (CBD) and its need, while the increased awareness of the importance of FGR provides an ideal environment for the wider implementation of FGM. The question whether such genetic monitoring could be combined or integrated into environmental and other forestry monitoring is addressed in the next section.

\subsection{Environmental Monitoring Complementarity with FGM}

Various existing monitoring programmes, striving to identify changes in ecosystem status over time, have different implementation designs and diverse aims. Environmental monitoring aims to regularly record the state of biological diversity over time. Genetic variation, as an integral part of biological diversity, needs special attention, and its monitoring can ensure its effective conservation [139]. For reasons of efficiency and economy, it might be beneficial to integrate genetic monitoring into existing environmental monitoring programmes. However, different goals and execution of the two make it necessary to consider the complementarity of environmental monitoring with FGM.

FGM is population level monitoring; it requires large enough plots to represent the entire population of a certain species. Currently, all active FGM plots focus on monitoring gene conservation units, following a recommendation by EUFORGEN [154]. Furthermore, the presence of several generations on the monitoring plot within the same population at the same time facilitates FGM. For example, changes of the genetic variation among the parental and the offspring generation can be indicative of ongoing genetic erosion [130]. According to Aravanopoulos et al. [26], considering a minimum area of four hectares is necessary for FGM with a minimum number of 150 adult trees of the target species. In contrast, NFI and ICP Forest Level I use small permanent monitoring plots with a limited number of trees (e.g., in Germany, seven trees at each permanent NFI plot were measured during the last NFI [155] and in Slovenia, the NFI in 2012 entailed measurements on 8.74 trees on average on a plot with a radius of $7.98 \mathrm{~m}$, and 11.35 trees on average on a plot with a radius of $13.82 \mathrm{~m}$ ) [156]. These monitoring plots are too small, i.e., not representative of a population for FGM. Another obstacle to the incorporation of FGM into NFIs is the location and ownership of NFI plots, as they are determined by the grid network and often fall in private forests, posing a risk for the long-term 
monitoring aims [26]. The same is true for ICP Level I plots. In contrast, ICP Level II plots are larger ( $0.25 \mathrm{ha})$ with broader research and monitoring targets. Therefore, FGM could be partly integrated into the ICP Level II monitoring scheme. This type of monitoring design (ICP Level II + FGM) can be advantageous because of additional information for both monitoring systems (environmental and genetic monitoring). For example, a European beech FGM plot, which included the ICP Level II plot, was established during the pilot study implementation in Germany [28]. FGM profited from the long-term ICP Level II data on stand health, soil conditions, phenology, climate/meteorology data, etc., which are all relevant for genetic monitoring. However, major methodological differences (e.g., phenology observation methods) can decrease the value and applicability of such data for FGM.

Various European projects and networks have established permanent research plots for various aims, which could be combined with FGM. These plots could provide a large amount of data relevant to FGM. In Table 4, a few examples of projects and monitoring networks which could be beneficial for FGM are presented. Some projects and programmes overlap concerning recorded data, e.g., phenology (ICP Level II, FORGER, EvolTree ISS, LIFEGENMON). However, this does not necessarily mean that exactly the same data is assessed. Problems could arise when it comes to the level of details in the protocols; which exact traits are assessed, how many stages are included, and at what time interval. Ideally, harmonized protocols should be used in all programmes assessing the same traits.

Table 4. Overview of long-term monitoring programmes and research projects.

\begin{tabular}{|c|c|c|c|}
\hline $\begin{array}{l}\text { Long-Term Monitoring } \\
\text { Programmes }\end{array}$ & $\begin{array}{l}\text { Key Features of Monitoring, Number of Existing } \\
\text { Study Sites or Area Covered }\end{array}$ & $\begin{array}{l}\text { Activities/Aims Related } \\
\text { to Genetic Monitoring } \\
\text { Yes/No }\end{array}$ & References \\
\hline ICP Level I & $\begin{array}{l}\text { Monitoring of stand health (crown condition, defoliation, survival/mortality, } \\
\text { etc.), foliar chemistry, soil condition. Over } 7500 \text { study sites } \\
\text { (around } 1500 \text { ha covered). }\end{array}$ & No & \\
\hline ICP Level II & $\begin{array}{l}\text { Monitoring of stand health (crown condition, defoliation, pests, diseases, } \\
\text { survival/mortality etc.), foliar chemistry, soil condition, soil solution } \\
\text { chemistry, tree growth, (increment etc.), phenology observations, air } \\
\text { pollution/quality (ozone-induced injury etc.), litterfall, species diversity } \\
\text { (ground vegetation diversity, etc.), soil water, deposition, } \\
\text { climate/meteorology observations. } 618 \text { study sites (around } 155 \text { ha covered). }\end{array}$ & No & [20] \\
\hline NFI & $\begin{array}{l}\text { Monitoring of tree species composition, growing stock, increment, forest } \\
\text { health conditions, state of timber and non-timber forest resources, etc. } \\
\text { Number of study sites differs from country to country. }\end{array}$ & No & {$[19,133]$} \\
\hline $\begin{array}{l}\text { Long-term growth and } \\
\text { yield observation and } \\
\text { experimental plots }\end{array}$ & $\begin{array}{l}\text { Monitoring of growth (mortality) and yield (DBH, height, increment) of } \\
\text { individual trees, stands and provenances under different types and intensity } \\
\text { of management in pure and mixed forest stands. }\end{array}$ & No (partly yes) & {$[136,137]$} \\
\hline \multicolumn{4}{|l|}{ Projects } \\
\hline FORGER & $\begin{array}{l}\text { Growth (DBH), phenology, health, survival, genetic variation, } \\
\text { climate/meteorology observations. } 16 \text { study sites within project countries. }\end{array}$ & Yes & [29] \\
\hline ManFor C.BD & $\begin{array}{l}\text { Climate/meteorology observations; testing and verifying effectiveness of } \\
\text { forest management options in meeting multiple objectives (production, } \\
\text { protection, biodiversity, etc.). Stand health, tree growth, species diversity. } \\
\text { Ten study sites within project countries. }\end{array}$ & No & [157] \\
\hline EvolTree ISS & $\begin{array}{l}\text { Tree growth (DBH, height, increment), soil water, stand health (mortality), } \\
\text { phenology, species diversity (trees, other plants, vertebrates, insects, and } \\
\text { microorganisms), climate/meteorology observations, genetic variation etc. } \\
\text { Seven study sites within project countries. }\end{array}$ & Yes & [158] \\
\hline EUFGIS & $\begin{array}{l}\text { Collection of information on unit level e.g., monthly temperature }\left({ }^{\circ} \mathrm{C}\right) \text {, total } \\
\text { annual mean precipitation (mm), heat sum and/or length of the growing } \\
\text { season (in days), accumulated moisture deficit, remarks on specific soil } \\
\text { characteristics, etc.; on species level e.g., status of the target tree population, } \\
\text { total number of reproducing trees per unit, sex ratio (if appropriate), } \\
\text { estimated share of the total area within the unit in which the species is } \\
\text { occurring (\%). At the moment the EUFGIS database contains information on } \\
3130 \text { gene conservation units and } 103 \text { tree species in } 34 \text { countries. }\end{array}$ & Yes/Under development & {$[150,151]$} \\
\hline GenTree & $\begin{array}{l}\text { Stand health (crown condition, crown size, defoliation, pests, diseases etc.), } \\
\text { soil condition, tree growth (DBH, height, increment etc.), species diversity } \\
\text { (ground vegetation diversity), climate/meteorology observations, genetic } \\
\text { variation. } 219 \text { study sites within project countries with focus on } \\
12 \text { tree species. }\end{array}$ & Yes & [30] \\
\hline LIFEGENMON & $\begin{array}{c}\text { Tree growth (DBH), phenology observations, climate/meteorology } \\
\text { observations, genetic variation. Six study sites within project countries } \\
\text { for two species. }\end{array}$ & Yes & [31] \\
\hline
\end{tabular}


In conclusion, FGM incorporation into the current European forest monitoring programmes and projects could provide knowledge on the adaptive potential of forests [159]. By introducing genetic monitoring into conservation programmes and sustainable forest management schemes, the assessment of information related to adaptive and neutral genetic diversity changes over time, on a species and/or on a population basis, is becoming a tangible goal. FGM can provide answers to many questions, but recording of the baseline data, as well as supplementary data (temperature, precipitation, growth, survival of trees, etc.), is of paramount importance for the successful tracking of genetic variation over time. Different stakeholders will profit from the data, such as forest owners, forest managers of protected areas, policy makers, and the scientific community.

\section{Conclusions}

High genetic variation and adaptive capacity of forests is influenced by many variables. Silviculture can have a significant impact on the genotypic and phenotypic variation per generation [40]. Depending on the species biology, ecology, forest management intensity, and other factors, the impact can be contradictory. Established forest monitoring systems such as long-term growth and yield observation and experimental plots give results and direct hints for forest management under climate change. Other monitoring systems such as ICP Forest regularly assess relationships between the state of forest ecosystems and anthropogenic as well as natural stress factors. However, there is a lack of complementarity between existing monitoring programmes and FGM. A particular result from the studies reviewed with a focus on forest management shows how contrarily management can affect the genetic and demographic structure of forest stands, calling for genetic monitoring in order to study the effects of all these different management systems. Therefore, development and implementation of the FGM system is of paramount importance for evaluating potential adaptability of forests in the light of forest management and changing climate. FGM can be used to detect the influence of forest management systems on genetic structure and diversity in areas where we can reasonably expect that there are no other strong forces (e.g., genetic drift because of stochastic events) that affect genetic variation over time [160]. In this way, FGM becomes a tool for forest managers that can provide recommendations for modifications in the stand management, by re-evaluating and adapting the existing management practices to maintain genetic diversity. Apart from mere monitoring of the state of the genetic system of forests, scientific results gained from FGM could be used by forest managers to maintain adaptability of future forests through adapted forest management. Results should also be communicated to policy makers in order to advance decisions supporting the sustainable use of FGR.

An example of such a transfer of scientific information to forest managers and policy is the LIFEGENMON project, which seeks to develop and test FGM protocols and discuss the possibilities to introduce genetic monitoring into conservation programmes and sustainable forest management schemes. Within this implementation project, the first steps of implementing a transnational FGM system have been taken. A considerable number of ongoing projects as well as legal documents point to the recognition of the importance of FGR. However, despite this recognition, FGM is still struggling with implementation. Common targets of ongoing environmental monitoring programmes/projects should be reconsidered so as to accommodate FGM as an essential part of regular monitoring. Integration of FGM as a component of the current pan-European forest monitoring programme would allow for a more accurate assessment of the status and adaptive potential of forest, benefiting forest management to ensure forest sustainability in the future. This review proves the necessity of FGM and provides a strong base for scientists, politicians, and foresters for further discussions on implementation FGM at a wider scale.

Acknowledgments: This work has been financially supported by the European Union's LIFE financial mechanism (LIFEGENMON project, LIFE13 ENV/SI/000148). Co-financiers of the project are the Ministry of the Environment and Spatial Planning and the Ministry for Agriculture, Forestry and Food of the Republic of Slovenia, the Bavarian Ministry of Food, Agriculture and Forestry, and the Ministry of Environment and Energy, Greece. Project Beneficiary Partners are: the Slovenian Forestry Institute (SFI), the Bavarian Office for Forest Seeding and Planting (ASP), Aristotle University of Thessaloniki (AUTH), the Centre for Information Service, Co-operation 
and Development of NGOs (CNVOS), the Decentralized Administration of Macedonia-Thrace (GDDAY-DAMT), and the Slovenia Forest Service (SFS). Thanks to Jean McCollister for proofreading the article.

Conflicts of Interest: The authors declare no conflict of interest.

\section{References}

1. Ledig, F.T. Human impacts on genetic diversity in forest ecosystems. Oikos 1992, 63, 87-108. [CrossRef]

2. Lefèvre, F. Human impacts on forest genetic resources in the temperate zone: An updated review. For. Ecol. Manag. 2004, 197, 257-271. [CrossRef]

3. Finkeldey, R.; Ziehe, M. Genetic implications of silvicultural regimes. For. Ecol. Manag. 2004, 197, $231-244$. [CrossRef]

4. Ratnam, W.; Rajora, P.O.; Finkeldey, R.; Aravanopoulos, F.; Bouvet, J.M.; Vaillancourt, R.E.; Kanashiro, M.; Fady, B.; Tomita, M.; Vinson, C. Genetic effects of forest management practices: Global synthesis and perspectives. For. Ecol. Manag. 2014, 333, 52-65. [CrossRef]

5. Spiecker, H. Silvicultural management in maintaining biodiversity and resistance of forests in Europe-temperate zone. J. Environ. Manag. 2003, 67, 55-65. [CrossRef]

6. Konnert, M.; Hussendörfer, E. Genetic variation of silver fir (Abies alba) in unevenaged forests ("Plenter" forest) in comparison with evenaged forests (Altersklassenwald). In Genetic Response of Forest Systems to Changing Environmental Conditions; Müller-Starck, G., Schubert, R., Eds.; Springer: Dordrecht, The Netherlands, 2001; pp. 307-320, ISBN 978-94-015-9839-2. [CrossRef]

7. Buiteveld, J.; Vendramin, G.G.; Leonardi, S.; Kamer, K.; Geburek, T. Genetic diversity and differentiation in European beech (Fagus sylvatica L.) stands varying in management history. For. Ecol. Manag. 2007, 247, 98-106. [CrossRef]

8. Konnert, M.; Hosius, B. Contribution of forest genetics for a sustainable forest management, Beitrag der Forstgenetik für ein nachhaltiges Waldmanagement. Forstarchiv 2010, 5, 170-174. [CrossRef]

9. Wernsdörfer, H.; Caron, H.; Gerber, S.; Cornu, G.; Rossi, V.; Mortier, F.; Gourlet-Fleury, S. Relationships between demography and gene flow and their importance for the conservation of tree populations in tropical forests under selective felling regimes. Conserv. Genet. 2009, 12, 15-29. [CrossRef]

10. Piotti, A.; Leonardi, S.; Buiteveld, J.; Geburek, T.; Gerber, S.; Kramer, K.; Vettori, C.; Vendramin, G.G. Comparison of pollen gene flow among four European beech (Fagus sylvatica L.) populations characterized by different management regimes. Heredity 2012, 108, 322-331. [CrossRef] [PubMed]

11. Paffetti, D.; Travaglini, D.; Buonamici, A.; Nocentini, S.; Vendramin, G.G.; Giannini, R.; Vettori, C. The influence of forest management on beech (Fagus sylvatica L.) stand structure and genetic diversity. For. Ecol. Manag. 2012, 284, 34-44. [CrossRef]

12. Piotti, A.; Leonardi, S.; Heuertz, M.; Buiteveld, J.; Geburek, T.; Gerber, S.; Kramer, K.; Vettori, C.; Vendramin, G.G. Within-population genetic structure in beech (Fagus sylvatica L.) stands characterized by different disturbance histories: Does forest management simplify population substructure? PLoS ONE 2013, 8, e73391. [CrossRef] [PubMed]

13. Fageria, M.S.; Rajora, O.P. Effects of silvicultural practices on genetic diversity and population structure of white spruce in Saskatchewan. Tree Genet. Genomes 2014, 10, 287-296. [CrossRef]

14. Westergren, M.; Bozic, G.; Ferreira, A.; Kraigher, H. Insignificant effect of management using irregular shelterwood system on the genetic diversity of European beech (Fagus sylvatica L.): A case study of managed stand and old growth forest in Slovenia. For. Ecol. Manag. 2015, 335, 51-59. [CrossRef]

15. Danusevicius, D.; Kerpauskaite, V.; Kavaliauskas, D.; Fussi, B.; Konnert, M.; Baliuckas, V. The effect of tending and commercial thinning on the genetic diversity of Scots pine stands. Eur. J. For. Res. 2016, 135, 1159-1174. [CrossRef]

16. Schaberg, P.G.; DeHayes, D.H.; Hawley, G.J.; Nijensohn, S.E. Anthropogenic alterations of genetic diversity within tree populations: Implications for forest ecosystem resilience. For. Ecol. Manag. 2008, 256, 855-862. [CrossRef]

17. Vos, P.; Meelis, E.; Ter Keurs, W.J. A framework for the design of ecological monitoring programs as a tool for environmental and nature management. Environ. Monit. Assess. 2000, 61, 317-344. [CrossRef]

18. Bengtsson, J.; Nilsson, S.G.; Franc, A.; Menozzi, P. Biodiversity, disturbances, ecosystem function and management of European forests. For. Ecol. Manag. 2000, 132, 39-50. [CrossRef] 
19. Corona, P.; Chirici, G.; McRoberts, R.E.; Winter, S.; Barbati, A. Contribution of large-scale forest inventories to biodiversity assessment and monitoring. For. Ecol. Manag. 2011, 262, 2061-2069. [CrossRef]

20. ICP Forests. The International Co-Operative Programme on Assessment and Monitoring of Air Pollution Effects on Forests. Available online: http:/ /icp-forests.net/ (accessed on 7 March 2016).

21. Leban, J.M.; Bontemps, J.D. Editorial:“Forest Inventories at the European level”. Ann. For. Sci. 2016, 73, 789-792. [CrossRef]

22. Namkoong, G.; Boyle, T.; Gregorius, H.R.; Joly, H.; Savolainen, O.; Ratman, W.; Young, A. Testing Criteria and Indicators for Assessing the Sustainability of Forest Management: Genetic Criteria and Indicators; Working Paper No. 10; Centre for International Forestry Research (CIFOR): Bogor, Indonesia, 1996. [CrossRef]

23. Namkoong, G.; Boyle, T.; El-Kassaby, Y.A.; Palmberg-Lerche, C.; Eriksson, G.; Gregorius, H.R.; Joly, H.; Kremer, A.; Savolainen, O.; Wickneswari, R.; et al. Criteria and Indicators for Sustainable Forest Management: Assessment and Monitoring of Genetic Variation; Forest Genetic Resources Working Paper: Rome, Italy, 2002.

24. Aravanopoulos, F.A. Genetic monitoring in natural perennial plant populations. Botany 2011, 89, 75-81. [CrossRef]

25. Koskela, J.; Lefèvre, F.; Schueler, S.; Kraigher, H.; Olrik, D.C.; Hubert, J.; Longauer, R.; Bozzano, M.; Yrjana, L.; Alizoti, P.; et al. Translating conservation genetics into management: Pan-European minimum requirements for dynamic conservation units of forest tree genetic diversity. Biol. Conserv. 2013, 157, 39-49. [CrossRef]

26. Aravanopoulos, F.A.; Tollefsrud, M.M.; Graudal, L.; Koskela, J.; Kätzel, R.; Soto, A.; Nagy, L.; Pilipovic, A.; Zhelev, P.; Bozic, G.; et al. Development of Genetic Monitoring Methods for Genetic Conservation Units of Forest Trees in Europe. European Forest Genetic Resources Programme (EUFORGEN); Bioversity International: Rome, Italy, 2015. Available online: http://www.euforgen.org/fileadmin/templates/euforgen.org/ upload/Publications/Thematic_publications/EUFORGEN-Genetic-monitoring-methods.pdf (accessed on 10 March 2016).

27. BLAG-Expert Group "Genetic Monitoring". Concept on the Genetic Monitoring for Forest Tree Species in the Federal Republic of Germany. 2004. Available online: http:/ / www.genres.de/ / fileadmin/SITE_BeiratFGR/content/Bilder/Concept_on_the_Genetic_Monitoring_for_Forest_Tree_Species_in_the_Federal_ Republic_of_Germany.pdf (accessed on 15 February 2016).

28. Konnert, M.; Maurer, W.; Degen, B.; Kätzel, R. Genetic monitoring in forests—Early warning and controlling system for ecosystematic changes. iForest 2011, 4, 77-81. [CrossRef]

29. FORGER: Towards the Sustainable Management of Forest Genetic Resources in Europe. Available online: http:/ / www.fp7-forger.eu/about-forger/objectives (accessed on 15 November 2016).

30. GenTree-Optimising the Management and Sustainable Use of Forest Genetic Resources in Europe. Available online: http:/ / www.GenTree-h2020.eu/about/overview / (accessed on 15 February 2017).

31. LIFEGENMON_Life for Forest Genetic Monitoring System. Available online: http://www.lifegenmon.si/ about/ (accessed on 15 February 2017).

32. GenMon-Genetisches Monitoring für Rotbuche und Fichte in Deutschland. Available online: https:/ / www.gen-mon.de/ (accessed on 15 February 2017).

33. Westergren, M.; Božič, G.; Kraigher, H. Silviculture in the light of genetics (M. Wraber 1950)—Principles, development and realisation untill 2005. Razprave 2006, 47, 231-245.

34. Westergren, M.; Božič, G.; Kraigher, H. Razvoj smernic za dinamično varstvo gozdnih genskih virov v spreminjajočih se razmerah v okolju. In Podnebne Spremembe: Vpliv na Gozd in Gozdarstvo, (Studia Forestalia SLOVENICA, no. 130); Jurc, M., Ed.; Biotehniška fakulteta, Oddelek za Gozdarstvo in Obnovljive Gozdne Vire: Ljubljana, Slovenia, 2007; pp. 487-488.

35. Kraigher, H. Ohranjanje in raba genskih virov v luči klimatskih sprememb: Tehnične smernice za ohranjanje in rabo genskih virov: Slovenija. Gozdarski Vestnik 2010, 68, 9.

36. Westergren, M.; Kraigher, H. Monitoring of forest genetic diversity. Gozdarski Vestnik 2011, 69, 322-326.

37. Westergren, M.; Kraigher, H. Genetski monitoring-Izhodišče gnetskega varstva gozdov: Tehnične smernice za ohranjanje in rabo genskih virov: Slovenija. Gozdarski Vestnik 2011, 69, 409-410.

38. Hansen, M.M.; Olivieri, I.; Waller, D.M.; Nielsen, E.E. Monitoring adaptive genetic responses to environmental change. Mol. Ecol. 2012, 21, 1311-1329. [CrossRef] [PubMed]

39. Alfaro, R.I.; Fady, B.; Vendramin, G.G.; Dawson, I.K.; Fleming, R.A.; Sáenz-Romero, C.; Lindig-Cisneros, R.A.; Murdock, T.; Vinceti, B.; Navarro, C.M.; et al. The role of forest genetic resources in responding to biotic and abiotic factors in the context of anthropogenic climate change. For. Ecol. Manag. 2014, 333, 76-87. [CrossRef] 
40. Lefèvre, F.; Boivin, T.; Bontemps, A.; Courbet, F.; Davi, H.; Durand-Gillmann, M.; Fady, B.; Gauzere, J.; Gidoin, C.; Karam, M.J.; et al. Considering evolutionary processes in adaptive forestry. Ann. For. Sci. 2014, 71, 723-739. [CrossRef]

41. Geburek, T.; Müller, F. How can silvicultural management contribute to genetic conservation? In Conservation and Management of Forest Genetic Resources in Europe; Geburek, T., Turok, J., Eds.; Arbora Publishers: Zvolen, Slovakia, 2005; pp. 1-693, ISBN 8096708813.

42. Europe, F.; Unece, F.A.O. State of Europe's Forests 2015, Status and Trends in Sustainable Forest Management in Europe; Ministerial Conference on the Protection of Forests in Europe, FOREST EUROPE Liaison Unit Madrid: Madrid, Spain, 2015; p. 314, ISBN 978-82-92980-05-7.

43. Duncker, P.S.; Barreiro, S.M.; Hengeveld, G.M.; Lind, T.; Mason, W.L.; Ambrozy, S.; Spiecker, H. Classification of forest management approaches: A new conceptual framework and its applicability to European forestry. Ecol. Soc. 2012, 17, 51. [CrossRef]

44. Ciancio, O.; Corona, P.; Lamonaca, A.; Portoghesi, L.; Travaglini, D. Conversion of clearcut beech coppices into high forests with continuous cover: A case study in central Italy. For. Ecol. Manag. 2006, 224, 235-240. [CrossRef]

45. Mattioli, W.; Ferrari, B.; Giuliarelli, D.; Mancini, L.D.; Portoghesi, L.; Corona, P. Conversion of mountain beech coppices into high forest: An example for ecological intensification. Environ. Manag. 2015, 56, 1159-1169. [CrossRef] [PubMed]

46. Coates, K.D.; Burton, P.J. A gap-based approach for development of silvicultural systems to address ecosystem management objectives. For. Ecol. Manag. 1997, 99, 337-354. [CrossRef]

47. Gamborg, C.; Larsen, J.B. 'Back to nature'-A sustainable future for forestry? For. Ecol. Manag. 2003, 179, 559-571. [CrossRef]

48. Arano, K.G.; Munn, I.A. Evaluating forest management intensity: A comparison among major forest landowner types. For. Policy Econ. 2006, 9, 237-248. [CrossRef]

49. Aravanopoulos, F.A. Conservation and monitoring of tree genetic resources in temperate forests. Curr. For. Rep. 2016, 2, 119-129. [CrossRef]

50. Pro Silva Principles. Pro Silva-Association of European Foresters Practicing Management Which Follows Natural Processes. 2012. Available online: http:/ / www.prosilva.org/wp-content/uploads/2016/12/PSprinciples-2012.pdf (accessed on 8 November 2017).

51. Schütz, J.-P. Development of close to nature forestry and the role of ProSilva Europe. Zb. Gozd. Lesar. 2011, $94,39-42$.

52. O'Hara, K. What is close-to-nature silviculture in a changing world? Forestry 2016, 89, 1-6. [CrossRef]

53. Geburek, T. Genetic diversity in forest trees-Its importance and potential human impact. In Conservation and Management of Forest Genetic Resources in Europe; Geburek, T., Turok, J., Eds.; Arbora Publishers: Zvolen, Slovakia, 2005; pp. 1-693, ISBN 8096708813.

54. Savolainen, O.; Kärkkäinen, K. Effect of forest management on gene pools. New For. 1992, 6, 329-345. [CrossRef]

55. Lande, R.; Barrowclough, G.F. Effective population size, genetic variation, and their use in population management. Viable Popul. Conserv. 1987, 87, 124.

56. Hosius, B.; Leinemann, L.; Konnert, M.; Bergmann, F. Genetic aspects of forestry in the Central Europe. Eur. J. For. Res. 2006, 125, 407-417. [CrossRef]

57. Diaci, J.; Rozenbergar, D.; Fidej, G.; Nagel, T. Challenges for Uneven-Aged Silviculture in Restoration of Post-Disturbance Forests in Central Europe: A Synthesis. Forests 2017, 8, 378. [CrossRef]

58. Westergren, M.; Bajc, M.; Finžgar, D.; Božič, G.; Kraigher, H. Identification of forest reproductive material origin of European beech using molecular methods. Gozdarski Vestnik 2017, 7, 328-343.

59. Schierup, M.H.; Christiansen, F.B. Inbreeding depression and outbreeding depression in plants. Heredity 1996, 77. [CrossRef]

60. Broadhurst, L.; Boshier, D. Seed provenance for restoration and management: Conserving evolutionary potential and utility. Genetic considerations in ecosystem restoration using native tree species. In A Thematic Study for the State of the World's Forest Genetic Resources; United Nations Food and Agriculture Organization: Rome, Italy, 2014; pp. 27-37. 
61. EU Marketing Requirements. Forest Reproductive Material. Available online: https://ec.europa. eu/food/plant/plant_propagation_material/legislation/eu_marketing_requirements_en (accessed on 28 February 2018).

62. Konert, M.; Fady, B.; Gömöry, D.; A'Hara, S.; Wolter, F.; Ducci, F.; Koskela, J.; Bozzano, M.; Maaten, T.; Kowalczyk, J. Use and Transfer of Forest Reproductive Material in Europe in the Context of Climate Change; European Forest Genetic Resources Programme (EUFORGEN); Bioversity International: Rome, Italy, 2015; Volume xvi, 75p.

63. Paquette, A.; Bouchard, A.; Cogliastro, A. Survival and growth of under-planted trees: A meta-analysis across four biomes. Ecol. Appl. 2006, 16, 1575-1589. [CrossRef]

64. Thomas, E.; Jalonen, R.; Loo, J.; Bozzano, M. Avoiding failure in forest restoration: The importance of genetically diverse and site-matched germplasm. Unasylva 2015, 66, 29-36.

65. Mátyás, C. Guidelines for the Choice of Forest Reproductive Material in the Face of Climate Change. Available online: http:/ / www.fp7-forger.eu/uploads/ForestReproductiveMaterial_climatechange_web.pdf (accessed on 28 February 2018).

66. Adams, W.T.; Zuo, J.; Shimizu, J.Y.; Tappeiner, J.C. Impact of alternative regeneration methods on genetic diversity in coastal Douglas-fir. For. Sci. 1998, 44, 390-396.

67. Rajora, O.P.; Pluhar, S.A. Genetic diversity impacts of forest fires, forest harvesting, and alternative reforestation practices in black spruce (Picea mariana). Theor. Appl. Genet. 2003, 106, 1203-1212. [CrossRef] [PubMed]

68. Kerr, G.; Haufe, J. Thinning practice. A Sylvicultural Guide; Foresty Commission: Bristol, UK, 2011; p. 54.

69. Degen, B.; Gregorius, H.R.; Scholz, F. ECO-GENE, a model for simulation studies on the spatial and temporal dynamics of genetic structures of tree populations. Silvae Genet. 1996, 45, 323-328.

70. Hussendörfer, E.; Konnert, M. Untersuchungen zur Bewirtschaftung von Weisstannen-und Buchenbeständen unter dem Aspekt der Erhaltung genetischer Variation. For. Snow Landsc. Res. 2000, 75, 187-204.

71. Dounavi, K.D.; Steiner, W.; Maurer, W.D. Effects of different silvicultural treatments on the genetic structure of European beech populations (Fagus sylvatica L.). In Continuous Cover Forestry; Von Gadow, K., Nagel, J., Saborowski, J., Eds.; Springer: Dordrecht, The Netherlands, 2002; pp. 81-90.

72. Ng, K.K.S.; Lee, S.L.; Ueno, S. Impact of selective logging on genetic diversity of two tropical tree species with contrasting breeding systems using direct comparison and simulation methods. For. Ecol. Manag. 2009, 257, 107-116. [CrossRef]

73. Manetti, M.C.; Becagli, C.; Sansone, D.; Pelleri, F. Tree-oriented silviculture: A new approach for coppice stands. iForest 2016, 9, 791. [CrossRef]

74. Bittencourt, J.V.M.; Sebbenn, A.M. Patterns of pollen and seed dispersal in a small, fragmented population of the wind-pollinated tree Araucaria angustifolia in southern Brazil. Heredity 2007, 99, 580-591. [CrossRef] [PubMed]

75. Chung, M.Y. Variation in demographic and fine-scale genetic structure with population-history stage of Hemerocallis taeanensis (Liliaceae) across the landscape. Ecol. Res. 2008, 23, 83-90. [CrossRef]

76. Epperson, B.K. Spatial structure of genetic variation within populations of forest trees. New For. 1992, 6, 257-278. [CrossRef]

77. Roženbergar, D.; Ficko, A.; Diaci, J. Contemporary Silviculture of Beech Forests. Zb. Gozd. Lesar. 2008, 87, 77-87.

78. Sagnard, F.; Oddou-Muratorio, S.; Pichot, C.; Vendramin, G.G.; Fady, B. Effects of seed dispersal, adult tree and seedling density on the spatial genetic structure of regeneration at fine temporal and spatial scales. Tree Genet. Genomes 2011, 7, 37-48. [CrossRef]

79. Müller-Starck, G.; Ziehe, M. Genetic Variation in European Populations of Forest Trees; JD Sauerländer's Verlag: Frankfurt am Main, Germany, 1991.

80. Raymond, P.; Bédard, S.; Roy, V.; Larouche, C.; Tremblay, S. The irregular shelterwood system: Review, classification, and potential applicaiton to forests affected by partial disturbances. J. For. 2009, 107, 405-413.

81. Neale, D.B. Genetic implications of shelterwood regeneration of Douglas fir in Southeast Oregon. For. Sci. 1985, 31, 995-1005.

82. Hart, C. Alternative Silvicultural Systems to Clear Cutting in Britain: A Review; Bulletin 115, HMSO; Forestry Commision: London, UK, 1995; p. 93, ISBN 9780117103344. 
83. Aune, P.S.; Redding, C.A. SEED-TREE METHOD. In Proceedings of the Genetics/Silviculture Workshop, Wenatchee, WA, USA, 27-31 August 1990; p. 224.

84. Keenan, R.J.; Kimmins, J.P. The ecological effects of clear-cutting. Environ. Rev. 1993, 1, 121-144. [CrossRef]

85. Amorini, E.; Manetti, M.C.; Turchetti, T.; Sansotta, A.; Villani, F. Impact of silvicultural system on Cryphonectria parasitica incidence and on genetic variability in a chestnut coppice in Central Italy. For. Ecol. Manag. 2001, 142, 19-31. [CrossRef]

86. Aravanopoulos, F.A.; Drouzas, A.D.; Alizoti, P.G. Electrophoretic and quantitative variation in chestnut (Castanea sativa Mill.) in Hellenic populations in old-growth natural and coppice stands. For. Snow Landsc. Res. 2001, 76, 429-434.

87. Chatziphilippidis, G.; Spyroglou, G. Sustainable Management of Coppice Forests in Greece. In Towards the Sustainable Use of Europe's Forests_Forest Ecosystem and Landscape Research: Scientific Challenges and Opportunities-EFI Proceedings No 49; Anderson, F., Birot, Y., Päivinen, R., Eds.; European Forestry Institute: Joensuu, Finland, 2004; pp. 51-60.

88. Mattioni, C.; Cherubini, M.; Micheli, E.; Villani, F.; Bucci, G. Role of domestication in shaping Castanea sativa genetic variation in Europe. Tree Genet. Genomes 2008, 4, 563-574. [CrossRef]

89. Valbuena-Carabaña, M.; González-Martínez, S.C.; Gil, L. Coppice forests and genetic diversity: A case study in Quercus pyrenaica Willd. from Central Spain. For. Ecol. Manag. 2008, 254, 225-232. [CrossRef]

90. Ortego, J.; Bonal, R.; Muñoz, A. Genetic consequences of habitat fragmentation in long-lived tree species: The case of the Mediterranean holm oak (Quercus ilex, L.). J. Heredity 2010, 101, 717-726. [CrossRef] [PubMed]

91. El-Kassaby, Y.A.; Benowicz, A. Effects of commercial thinning on genetic, plant species and structural diversity in second growth Douglas-fir (Pseudotsuga menziesii (Mirb.) Franco) stands. For. Genet. 2000, 7, 193-203.

92. Sjölund, M.J.; Jump, A.S. Coppice management of forests impacts spatial genetic structure but not genetic diversity in European beech (Fagus sylvatica L.). For. Ecol. Manag. 2015, 336, 65-71. [CrossRef]

93. Rajora, O.P.; Rahman, M.H.; Buchert, G.P.; Dancik, B.P. Microsatellite DNA analysis of genetic effects of harvesting in old-growth eastern white pine (Pinus strobus) in Ontario, Canada. Mol. Ecol. 2000, 9, 339-348. [CrossRef] [PubMed]

94. Epperson, B.K.; Chung, M.G. Spatial genetic structure of allozyme polymorphisms within populations of Pinus strobus (Pinaceae). Am. J. Bot. 2001, 88, 1006-1010. [CrossRef] [PubMed]

95. Macdonald, S.E.; Thomas, B.R.; Cherniawsky, D.M.; Purdy, B.G. Managing genetic resources of lodgepole pine in west-central Alberta: Patterns of isozyme variation in natural populations and effects of forest management. For. Ecol. Manag. 2001, 152, 45-58. [CrossRef]

96. Sork, V.L.; Davis, F.W.; Smouse, P.E.; Apsit, V.J.; Dyer, R.J.; Fernandez-M, J.F.; Kuhn, B. Pollen movement in declining populations of California Valley oak, Quercus lobata: Where have all the fathers gone? Mol. Ecol. 2002, 11, 1657-1668. [CrossRef] [PubMed]

97. Lee, C.T.; Wickneswari, R.; Mahani, M.C.; Zakri, A.H. Effect of selective logging on the genetic diversity of Scaphium macropodum. Biol. Conserv. 2002, 104, 107-118. [CrossRef]

98. Lee, C.T.; Wickneswari, R.; Clyde, M.M.; Zakri, A.H. Maintenance of genetic diversity in Parkia speciosa in logged-over forests. J. Trop. For. Sci. 2002, 14, 163-178.

99. Obayashi, K.; Tsumura, Y.; Ihara-Ujino, T.; Niiyama, K.; Tanouchi, H.; Suyama, Y.; Washitani, I.; Lee, CT.; Lee, SL.; Muhammad, N. Genetic diversity and outcrossing rate between undisturbed and selectively logged forests of Shorea curtisii (Dipterocarpaceae) using microsatellite DNA analysis. Int. J. Plant Sci. 2002, 163, 151-158. [CrossRef]

100. Glaubitz, J.C.; Murrell, J.C.; Moran, G.F. Effects of native forest regeneration practices on genetic diversity in Eucalyptus consideniana. Theor. Appl. Genet. 2003, 107, 422-431. [CrossRef] [PubMed]

101. Glaubitz, J.C.; Wu, H.X.; Moran, G.F. Impacts of silviculture on genetic diversity in the native forest species Eucalyptus sieberi. Conserv. Genet. 2003, 4, 275-287. [CrossRef]

102. El-Kassaby, Y.A.; Dunsworth, B.G.; Krakowski, J. Genetic evaluation of alternative silvicultural systems in coastal montane forests: Western hemlock and amabilis fir. Theor. Appl. Genet. 2003, 107, 598-610. [CrossRef] [PubMed]

103. Robledo-Arnuncio, J.J.; Alia, R.; Gil, L. Increased selfing and correlated paternity in a small population of a predominantly outcrossing conifer, Pinus sylvestris. Mol. Ecol. 2004, 13, 2567-2577. [CrossRef] [PubMed] 
104. Robledo-Arnuncio, J.J.; Smouse, P.E.; Gil, L.; Alıa, R. Pollen movement under alternative silvicultural practices in native populations of Scots pine (Pinus sylvestris L.) in central Spain. For. Ecol. Manag. 2004, 197, 245-255. [CrossRef]

105. Lowe, A.J.; Boshier, D.; Ward, M.; Bacles, C.F.E.; Navarro, C. Genetic resource impacts of habitat loss and degradation; reconciling empirical evidence and predicted theory for neotropical trees. Heredity 2005, 95, 255-273. [CrossRef] [PubMed]

106. Hawley, G.J.; Schaberg, P.G.; DeHayes, D.H.; Brissette, J.C. Silviculture alters the genetic structure of an eastern hemlock forest in Maine, USA. Can. J. For. Res. 2005, 35, 143-150. [CrossRef]

107. Nijensohn, S.E.; Schaberg, P.G.; Hawley, G.J.; DeHayes, D.H. Genetic subpopulation structuring and its implications in a mature eastern white pine stand. Can. J. For. Res. 2005, 35, 1041-1052. [CrossRef]

108. Maghuly, F.; Pinsker, W.; Praznik, W.; Fluch, S. Genetic diversity in managed subpopulations of Norway spruce [Picea abies (L.) Karst.]. For. Ecol. Manag. 2006, 222, 266-271. [CrossRef]

109. Degen, B.; Blanc, L.; Caron, H.; Maggia, L.; Kremer, A.; Gourlet-Fleury, S. Impact of selective logging on genetic composition and demographic structure of four tropical tree species. Biol. Conserv. 2006, 131, 386-401. [CrossRef]

110. Lourmas, M.; Kjellberg, F.; Dessard, H.; Joly, H.I.; Chevallier, M.H. Reduced density due to logging and its consequences on mating system and pollen flow in the African mahogany Entandrophragma cylindricum. Heredity 2007, 99, 151-160. [CrossRef] [PubMed]

111. Azevedo, V.C.; Kanashiro, M.; Ciampi, A.Y.; Grattapaglia, D. Genetic structure and mating system of Manilkara huberi (Ducke) A. Chev.; a heavily logged Amazonian timber species. J. Heredity 2007, 98, 646-654. [CrossRef] [PubMed]

112. Marquardt, P.E.; Echt, C.S.; Epperson, B.K.; Pubanz, D.M. Genetic structure, diversity, and inbreeding of eastern white pine under different management conditions. Can. J. For. Res. 2007, 37, 2652-2662. [CrossRef]

113. Lise, Y.; Kaya, Z.; Isik, F.; Sabuncu, R.; Kandemir, I.; Onde, S. The impact of over-exploitation on the genetic structure of Turkish red pine (Pinus brutia Ten.) populations determined by RAPD markers. Silva Fenn. 2007, 41, 211. [CrossRef]

114. Lee, K.S.; Wickneswari, R.; Choong, C.Y. Stand Structure and the Genetic Diversity of Koompassia malaccensis and Dryobalanops aromatica in Unlogged and Logged-over Stands. Sains Malaysiana 2007, 36, 233-242.

115. Cloutier, D.; Kanashiro, M.; Ciampi, A.Y.; Schoen, D.J. Impact of selective logging on inbreeding and gene dispersal in an Amazonian tree population of Carapa guianensis Aubl. Mol. Ecol. 2007, 16, 797-809. [CrossRef] [PubMed]

116. Silva, M.B.; Kanashiro, M.; Ciampi, A.Y.; Thompson, I.; Sebbenn, A.M. Genetic effects of selective logging and pollen gene flow in a low-density population of the dioecious tropical tree Bagassa guianensis in the Brazilian Amazon. For. Ecol. Manag. 2008, 255, 1548-1558. [CrossRef]

117. de Lacerda, A.E.B.; Kanashiro, M.; Sebbenn, A.M. Effects of Reduced Impact Logging on genetic diversity and spatial genetic structure of a Hymenaea courbaril population in the Brazilian Amazon Forest. For. Ecol. Manag. 2008, 255, 1034-1043. [CrossRef]

118. Sebbenn, A.M.; Degen, B.; Azevedo, V.C.; Silva, M.B.; de Lacerda, A.E.; Ciampi, A.Y.; Kanashiro, M.; da Carneiro, F.S.; Thompson, I.; Loveless, M.D. Modelling the long-term impacts of selective logging on genetic diversity and demographic structure of four tropical tree species in the Amazon forest. For. Ecol. Manag. 2008, 254, 335-349. [CrossRef]

119. André, T.; Lemes, M.R.; Grogan, J.; Gribel, R. Post-logging loss of genetic diversity in a mahogany (Swietenia macrophylla King, Meliaceae) population in Brazilian Amazonia. For. Ecol. Manag. 2008, 255, 340-345. [CrossRef]

120. Dubreuil, M.; Riba, M.; Gonzalez-Martinez, S.C.; Vendramin, G.G.; Sebastiani, F.; Mayol, M. Genetic effects of chronic habitat fragmentation revisited: Strong genetic structure in a temperate tree, Taxus baccata (Taxaceae), with great dispersal capability. Am. J. Bot. 2010, 97, 303-310. [CrossRef] [PubMed]

121. Robichaud, R.L.; Glaubitz, J.C.; Rhodes, O.E.; Woeste, K. Genetic consequences of harvest in a mature second-growth stand of black walnut (Juglans nigra L.). Ann. For. Sci. 2010, 67, 702. [CrossRef]

122. Carneiro, F.S.; Lacerda, A.E.B.; Lemes, M.R.; Gribel, R.; Kanashiro, M.; Wadt, L.H.O.; Sebbenn, A.M. Effects of selective logging on the mating system and pollen dispersal of Hymenaea courbaril L.(Leguminosae) in the Eastern Brazilian Amazon as revealed by microsatellite analysis. For. Ecol. Manag. 2011, 262, 1758-1765. [CrossRef] 
123. Fageria, M.S.; Rajora, O.P. Effects of harvesting of increasing intensities on genetic diversity and population structure of white spruce. Evol. Appl. 2013, 6, 778-794. [CrossRef] [PubMed]

124. Rajendra, K.C.; Seifert, S.; Prinz, K.; Gailing, O.; Finkeldey, R. Subtle human impacts on neutral genetic diversity and spatial patterns of genetic variation in European beech (Fagus sylvatica L.). For. Ecol. Manag. 2014, 319, 138-149. [CrossRef]

125. Sola, G.; El Mujtar, V.; Tsuda, Y.; Vendramin, G.G.; Gallo, L. The effect of silvicultural management on the genetic diversity of a mixed Nothofagus forest in Lanín Natural Reserve, Argentina. For. Ecol. Manag. 2016, 363, 11-20. [CrossRef]

126. Hausler, A.; Scherer-Lorenzen, M. Sustainable Forest Management in Germany: The Ecosystem Approach of the Biodiversity Convention Reconsidered; Federal Ministry of Environment: Bonn, Germany, 2001; p. 65.

127. ZGS. Data on Forest Managing Practices and Development Stages in Slovenia; Slovenia Forest Service: Ljubljana, Slovenia, 2016.

128. Arabatzis, G. European Union, Common Agricultural Policy (CAP) and the afforestation of agricultural land in Greece. New Medit 2015, 4, 48-54.

129. Ministry of Environment and Energy. Report of Forest Service Activities. Available online: http:/ /www.ypeka. gr/LinkClick.aspx?fileticket=fjsA7Em8z0A\%3d\&tabid=588\&language=el-GR (accessed on 28 February 2018).

130. Hoban, S.; Arntzen, J.A.; Bruford, M.W.; Godoy, J.A.; Rus Hoelzel, A.; Segelbacher, G.; Carles, V.; Bertorelle, G. Comparative evaluation of potential indicators and temporal sampling protocols for monitoring genetic erosion. Evol. Appl. 2014, 7, 984-998. [CrossRef] [PubMed]

131. Charlier, J. Monitoring Gene Level Biodiversity-Aspects and Considerations in the Context of Conservation. Ph.D. Thesis, Department of Zoology, Stockholm University, Stockholm, Sweden, 2011; Printed in Sweden by US-AB.

132. Vilhar, U.; Žlindra, D.; Marenče, M.; Sinjur, I.; Skudnik, M. 30 Let Spremljanja Stanja Gozdov v Sloveniji; The Silva Slovenica Publishing Centre: Ljubljana, Slovenia, 2017; p. 63. [CrossRef]

133. Nieuwenhuis, M. Terminology of Forest Management Planning (Forsteinrichtung). Terms and Definitions in English; IUFRO World Series Vol. 9-en; IUFRO 4.04.07 SilvaPlan and SilvaVoc: Vienna, Austria, 2000; p. 166.

134. Michel, A.; Seidling, W. Forest Condition in Europe: 2016 Technical Report of ICP Forests; Report under the UNECE Convention on Long-Range Transboundary Air Pollution (CLRTAP); BFWDokumentation 23/2016; BFW Austrian Research Centre for Forests: Vienna, Austria, 2016; p. 206.

135. Mátyás, C. Forecasts needed for retreating forests. Nature 2010, 464, 1271. [CrossRef] [PubMed]

136. Pretzsch, H. Forest Dynamics, Growth, and Yield; Springer: Berlin/Heidelberg, Germany, 2009; pp. 1-39, ISBN 978-3-540-88307-4.

137. Larocque, G.R. Ecological Forest Management Handbook; CRC Press: Boca Raton, FL, USA, 2016; p. 604, ISBN 9781482247855.

138. Graudal, L.; Aravanopoulos, F.; Bennadji, Z.; Changtragoon, S.; Fady, B.; Kjær, E.D.; Loo, J.; Ramamonjisoa, L.; Vendramin, G.G. Global to local genetic diversity indicators of evolutionary potential in tree species within and outside forests. For. Ecol. Manag. 2014, 333, 35-51. [CrossRef]

139. Fussi, B.; Westergren, M.; Aravanopoulos, F.; Baier, R.; Kavaliauskas, D.; Finzgar, D.; Alizoti, P.; Bozic, G.; Avramidou, E.; Konnert, M.; et al. Forest genetic monitoring: An overview of concepts and definitions. Environ. Monit. Assess. 2016, 188, 493. [CrossRef] [PubMed]

140. Schwartz, M.K.; Luikart, G.; Waples, R.S. Genetic monitoring as a promising tool for conservation and management. Trends Ecol. Evol. 2007, 22, 25-33. [CrossRef] [PubMed]

141. Convention on Biological Diversity. UN Conference on Environment and Development, Rio de Janeiro, 1992. Available online: https: / www.cbd.int/history/ (accessed on 30 July 2015).

142. Report of the Fourth Steering Committee Meeting, EUFORGEN. Zidlochovice, Czech Republic. Available online: http:/ / www.euforgen.org/publications / publication/ euforgen-steering-committee-report-of-thefourth-meeting/ (accessed on 13 November 2017).

143. Summary of the First Meeting of Scattered Broadleaves Network, EUFORGEN. Copenhagen, Denmark, 2005. Available online: http://www.euforgen.org/publications/publication/scattered-broadleaves-networksummary-of-the-first-meeting/ (accessed on 13 November 2017). 
144. Report of the Sixth Steering Committee Meeting, EUFORGEN. Thessaloniki, Greece Summary of the Meeting Technical and Financial Reports (Phase III) EUFORGEN Phase IV (2010-2014). Available online: http:/ / www.euforgen.org/publications / publication/ euforgen-steering-committee-report-on-thesixth-meeting/ (accessed on 13 November 2017).

145. Report of the Seventh Steering Committee Meeting, EUFORGEN. Vienna, Austria. Available online: http:/ / www.euforgen.org/publications / publication/euforgen-steering-committee-report-of-theseventh-meeting/ (accessed on 13 November 2017).

146. Summary of the First Meeting of Working Group on Genetic Monitoring, EUFORGEN. Rome, Italy. Available online: http:/ / www.euforgen.org/publications/publication/working-group-on-geneticmonitoring-summary-of-the-first-meeting/ (accessed on 13 November 2017).

147. CBD. COP 10 Decision X/2. Strategic Plan for Biodiversity 2011-2020. Available online: http:/ / www.cbd. int/decision/cop/?id=12268 (accessed on 10 November 2017).

148. CBD. Aichi Biodiversity Targets. Available online: http://www.cbd.int/sp/targets/ (accessed on 10 November 2017).

149. The EU Biodiversity Strategy 2020. Available online: http://ec.europa.eu/environment/nature/ biodiversity/comm2006/2020.htm (accessed on 4 December 2017).

150. European Information System on Forest Genetic Resources (EUFGIS). Available online: http:/ / portal.eufgis. org/genetic-conservation-units/ (accessed on 14 November 2016).

151. European Forest Genetic Resources Programme (EUFORGEN). Available online: http:/ / www.euforgen.org/ (accessed on 14 November 2016).

152. Conservation of Forest Genetic Resources in Canada (CONFORGEN). Available online: http:/ / www.conforgen. ca/ (accessed on 28 February 2018).

153. Asia Pacific Forest Genetic Resources Programme (APFORGEN). Available online: http://www.apforgen. org/ (accessed on 28 February 2018).

154. Summary of the Third Meeting of Scattered Broadleaves Network, EUFORGEN. Drøbak, Norway. Available online: http://www.euforgen.org/fileadmin/templates/euforgen.org/upload/Documents / Meeting_Summaries/SB03_meeting_summary.pdf (accessed on 13 November 2017).

155. The Forests in Germany—Selected Results of the Third National Forest Inventory. Item No: BMEL15037. Available online: http:/ / www.bmel.de/SharedDocs/Downloads/EN/Publications / ForestsInGermanyBWI.pdf?_blob=publicationFile (accessed on 10 April 2017).

156. FECS. Forest and Forest Ecosystem Condition Survey Dataset; Slovenian Forestry Institute: Ljubljana, Slovenia, 2012.

157. ManFor CBD 2010-2015 Life Environment Project LIFE09 ENV/IT/000078. Managing Forests for Multiple Purposes: Carbon, Biodiversity and Socio-Economic Wellbeing. Available online: http:/ /www.manfor.eu/ new / ?page_id=102 (accessed on 12 October 2016).

158. EVOLETREE—Evolution of TREEs as Drivers of Terrestrial Biodiversity. Available online: http:/ /www.evoltree. eu/index.php/network/mission (accessed on 15 November 2016).

159. Fady, B.; Cottrell, J.; Ackzell, L.; Alía, R.; Muys, B.; Prada, A.; González-Martínez, S.C. Forests and global change: What can genetics contribute to the major forest management and policy challenges of the twenty-first century? Reg. Environ. Chang. 2016, 16, 927-939. [CrossRef]

160. Laikre, L.; Larsson, L.C.; Palmé, A.; Charlier, J.; Josefsson, M.; Ryman, N. Potentials for monitoring gene level biodiversity: Using Sweden as an example. Biodivers. Conserv. 2008, 17, 893-910. [CrossRef]

(C) 2018 by the authors. Licensee MDPI, Basel, Switzerland. This article is an open access article distributed under the terms and conditions of the Creative Commons Attribution (CC BY) license (http://creativecommons.org/licenses/by/4.0/). 